INGENIERIA MECANICA

\title{
Desarrollo de vivienda ecosostenible para sectores vulnerables
}

MECHANICAL ENGINEERING

\section{Eco-Sustainable housing development for vulnerable population}

\author{
Edgar A. Salazar*§, Juan F. Arroyave*, Ivan Y. Moreno*, \\ * Universidad Tecnológica de Pereira Facultad de Tecnología. Programa de Tecnología Mecánica., \\ Colombia. \\ §edgarsalazar@utp.edu.co,jfa@utp.edu.co,yes@utp.edu.co \\ (Recibido: 29 de enero del 2013 - Aceptado: 9 de Octubre del 2013)
}

\begin{abstract}
Resumen
El trabajo consiste en el montaje de un módulo habitacional ecosostenible para sectores vulnerables (en el caso de este proyecto: Fundación "Kyrios", centro de restauración), fabricado en plástico y tetrapack reciclado, proveniente de residuos en procesos de empaque de diferentes empresas; con instalación de sistemas ecoeficientes (panel fotovoltaico, y colector solar) para suplir demandas energéticas eléctrica y térmica respectivamente. Se realizan pruebas de resistencia mecánica, conductividad térmica, acústica y permeabilidad del material de construcción que garantizan las condiciones de habitabilidad adecuadas.
\end{abstract}

Palabras clave: Desarrollo sostenible, energías alternativas, fuentes renovables, reciclaje de plásticos.

\begin{abstract}
The project consists of the installation of an environmentally sustainable housing module (In this project, for the "Kyrios" Foundation, Rehabilitation Center): the module was built with waste plastic materials discarded from industrial packaging processes. Different sustainable systems were installed (photovoltaic system, solar collector) to satisfy electricity and thermal energy demands. In order to satisfy the conditions of housing, different tests were performed on the construction material such as mechanical resistance, thermal and acoustic conductivity and permeability.
\end{abstract}

Keywords: Sustainable development, Alternative energy, renewable sources recycling plastics. 


\section{Introduction}

In Colombia, the social welfare housing is developed to benefit the poorest people of the country and whose incomes are less than four legally current minimum wages $(\$ 589,500$ in 2013: U\$ 312,7). This social housing must meet the quality standards of appropriate housing, according to the booklet \#21 named "The human right to adequate housing," issued by the office of the High Commissioner for Human Rights UN. And further design and construction must ensure the sustainable use of natural resources (Ministry of Environment, Housing and Territorial Development, 2011).

The concept of sustainable building focuses primarily on optimizing the buildings life expectancy aiming to use properly the environmental resources at hand, to mitigate the environmental impact of emissions and pollutants and finally to reuse the latter for the benefit of the users. The sustainable construction takes into account the management of the Life Cycle of both materials and components used, the use of recyclable materials, the rational and efficient use of energy, the saving and reuse of water, the use of alternative sources of energy, the improvement of construction techniques and the promotion of more eco-friendly habits to the final users, among others.

This article presents a sustainable housing module with sustainable architecture and construction criteria, namely: energy saving and use of renewable energy sources, recycling, rational water management, pollution reduction, use of sound and thermal insulators, low economic and social cost. The project has been implemented in the Kyrios foundation. Kyrios' mission is to help people who are in distress, abandonment, vulnerability, poverty, etc. providing the right conditions that lead to their social reimmersion. Such people have been victims of social problems as substance abuse, family violence, displacement, etc. Given the foundation has no government support; the contribution of this project has been convenient and appropriate. A Stand-Alone Solar Power System: off-grid solar and remote power generation implies monthly savings on utilities bills. This project has become an encouraging important reference for other private initiatives and government agencies behind similar projects of social housing with beneficial environmental impact and low cost.

\subsection{Solid waste management in the region}

Solid Waste Management has become a priority for the country in a wide range of topics related to environmental issues. Integrated Waste Management is the umbrella term applied to all activities associated with transportation, handling, control and disposal of various waste streams within society, so they turn compatible with the environment and public health.

The Colombian Constitution in its chapter III "Of the Collective Rights and the Environment", article 79 reads: "Everybody has the right to enjoy a healthy environment... "It is the duty of the nation to protect the diversity and integrity of the environment, and preserve the areas with special environmental importance and to promote the education to achieve these objectives", And its article 80: "The state will organize the management and use of the natural resources to guarantee their sustainable development, preservation, restoration and substitution. In addition the state should prevent and control the environmental degradation factors, impose legal sanctions and demand adequate compensation for the damages caused".

The decree 1713 of 2002 defines the "Use" within the framework of Integral Solid Waste as "the process by which through an integral solid waste management, the recovered materials returning to economic and productive cycle efficiently, through reuse, recycling, combustion with purposes of power generation, composting or any other modality that involves health, environmental and / or economic benefits". Table 1 shows the physical composition of existing solid waste in the instance city of Pereira (Planning Secretary of Pereira, 2008), taken from an average sample of $2013 \mathrm{~kg}$. It can be clearly evidenced in this study that the plastic materials have the highest percentage share of the total waste. The use of plastic as raw material in brick production has already been tried by different national and international researchers (Pineda, 


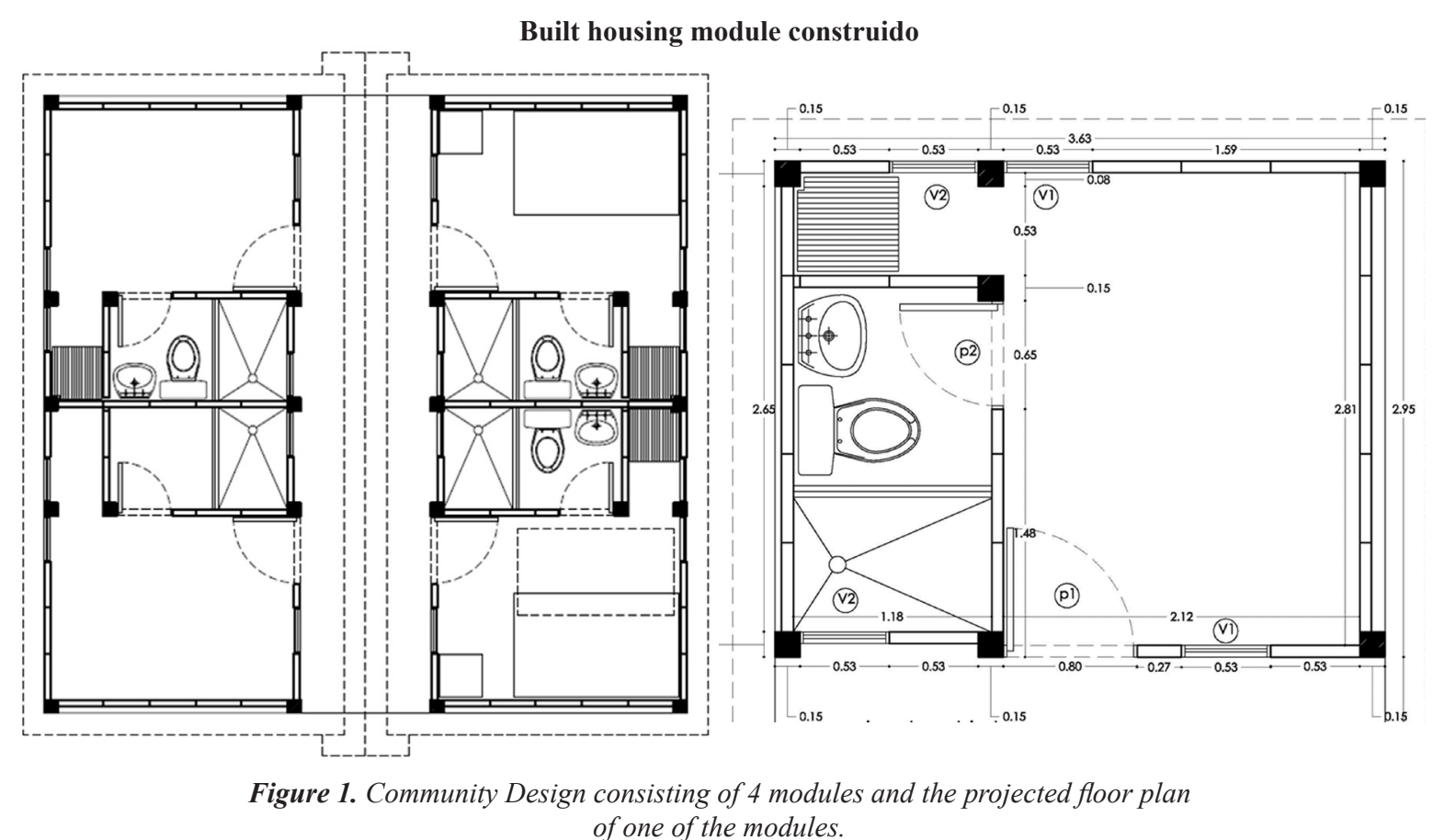

2012) and (Gaggino, 2008; Calcagno, 2012 and Sun Chi, 2004), and various reports published in online videos (Bolaños 2011).

Table 1. Physical Composition of Solid Waste in Pereira, 2008 (Secretary of Education, Major Office, 2008)

\begin{tabular}{cc}
\hline Components & Weight (\%) \\
\hline Food leftovers & 60 \\
Paper & 5,2 \\
Carton & 3,2 \\
Fabric & 4 \\
Rubber & 0,6 \\
Wood & 1,3 \\
Glass & 3,2 \\
Metals & 2,2 \\
Plastic & 16,2 \\
Others & 4,1 \\
Total & 100 \\
\hline
\end{tabular}

\section{Methodology}

The work done in this research is presented in the following steps: module design, materials, construction and testing of the material used.

\subsection{Housing module}

The proposed housing module was designed to be inhabited by two people, providing the minimum conditions of habitability and comfort.
The construction is based on bioclimatic and bio constructive criteria that optimize energy resources in its construction, preservation and maintenance. In the beginning the construction of 4 housing units had been projected. Those units would have been capable of providing accommodation for 4 couples (Figure1), and eventually of optimizing resources in terms of electricity, health, roofing, etc. However, by the time this report was written, only one module was built due to budget issues. It will serve as a reference for the other three yet to be built. Figure 1 shows a floor plan of the module with detailed measures in function of the minimum dimensions required.

\subsection{Built housing material}

In addition to the walls and columns made of plastic materials, roof tiles were manufactured out of recycled tetrapack. Bricks and columns processing begins with the collection and reception of materials (Figure 2). Basically, discarded bags and bottles from the packaging process of soft drinks and snacks are used for these bricks. The main waste materials found are primarily low and high density polyethylene (LDPE and HDPE) polypropylene (PP) and Polyethylene Terephthalate (PET). From the collected material the plastic mixture for construction is prepared. Due to the structural 


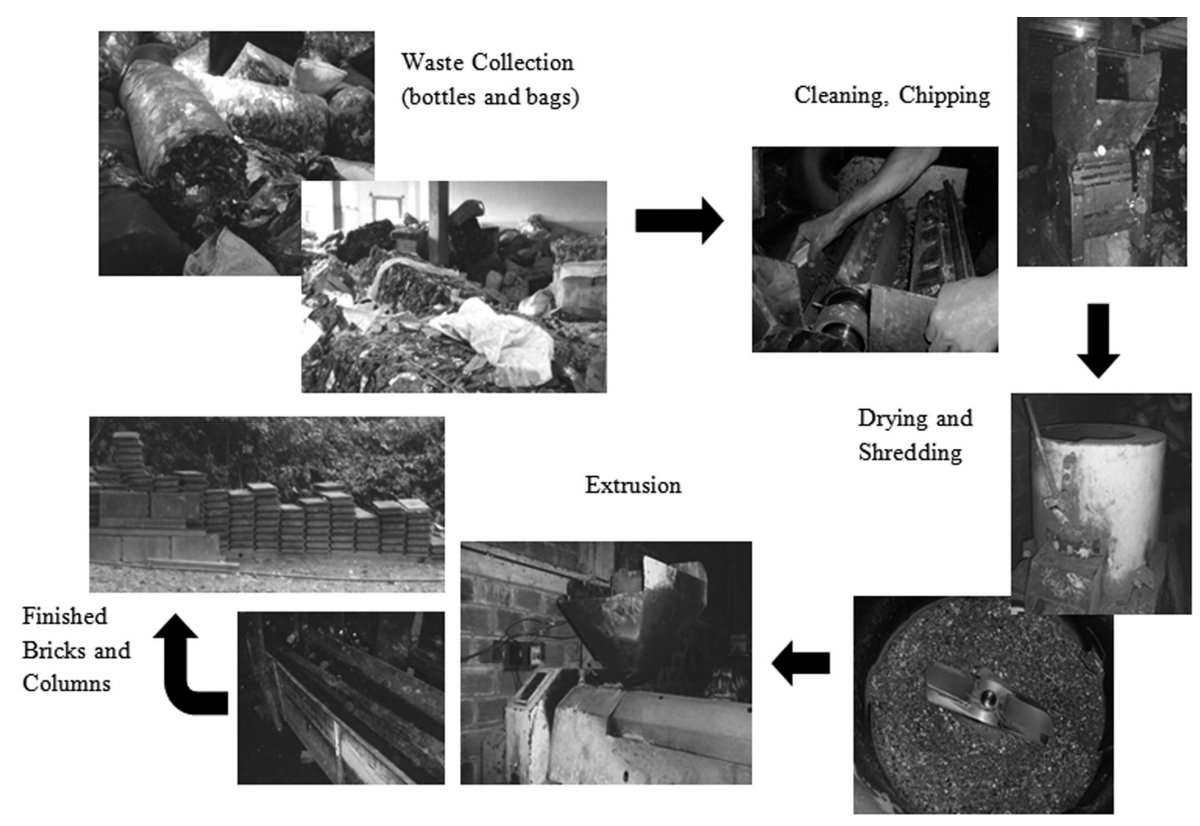

Figure 2. Plastic bricks and columns manufacturing.

function of the columns, their mixture requires a larger amount of PET in comparison to the bricks' mixture. The material is cleaned and selected manually to start the steps of chipping and then shredding until sizes smaller than 2 $\mathrm{mm}$ are obtained. Material mixture is preheated to remove moisture and metals are filtered and finally the material is melted and extruded into three kind of molds (whole brick, half a brick and column). The molds are immersed in water to the required solidification.
The design of the bricks (Figure 3) allows overlapping assembly to complete the walls according to the architectural design. Both bricks and columns have tongue and groove joints that allow the proper fitting for the consolidation of the walls. The distance between columns must ensure the assembly of a number of half and whole bricks to avoid cutting some of them, likewise this distance must also provide the walls with sufficient stiffness.
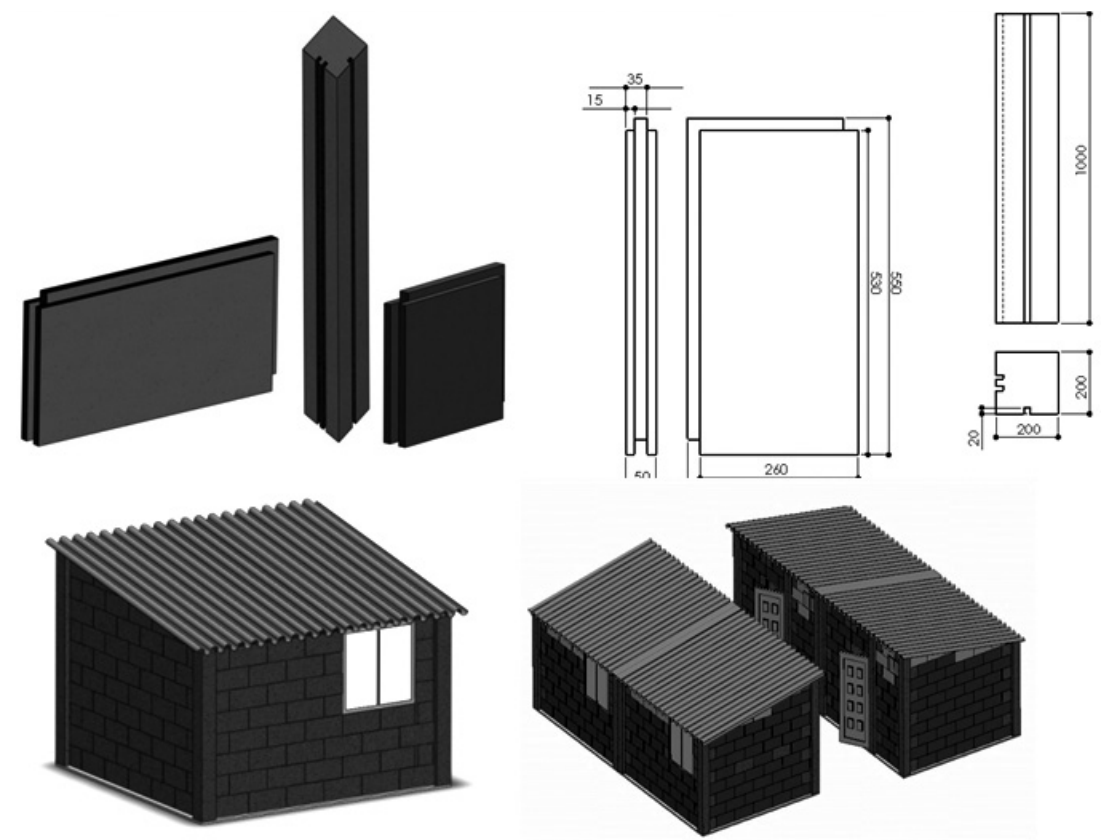

Figure 3. Scheme and measures of the bricks (half, whole and column). 3D graphic of the module and lay-out of the 4 modules to be built. 


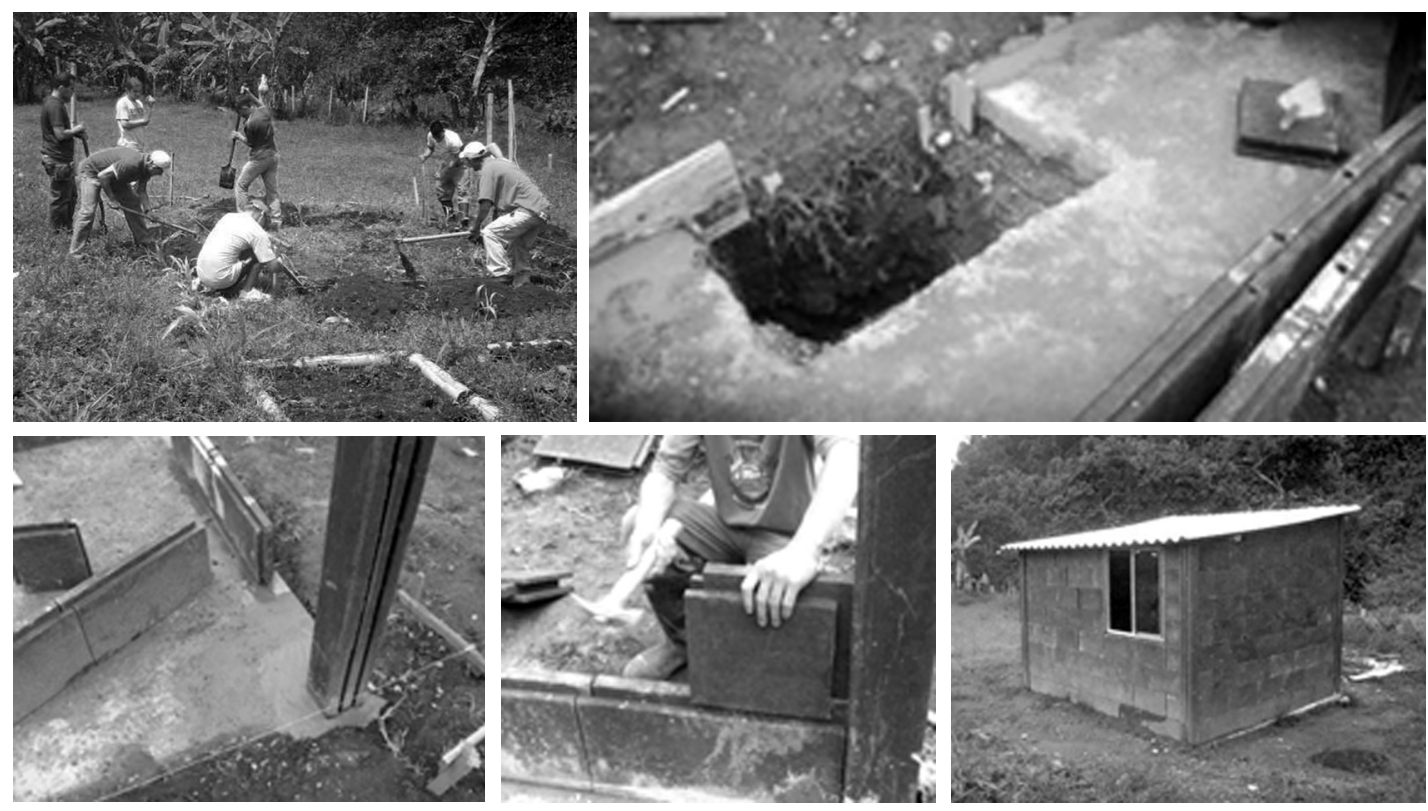

Figure 4. Ground Preparation, concrete base and columns foundations. Bricks and Columns Assembly. Finished Module.

\subsection{Module building}

The assembly process of the module begins with ground preparation (welded mesh and gravel foundation) for the concrete base, and raising the necessary formworks that will support the columns following the construction drawings (Figure 1). One advantage of this type of construction is that doesn't need underground foundations for the walls due to its relatively low weight. To stiffen the module, underground foundations are only required in the places where the columns will be placed. Based on the columns, the overlapping assembly of the bricks is done

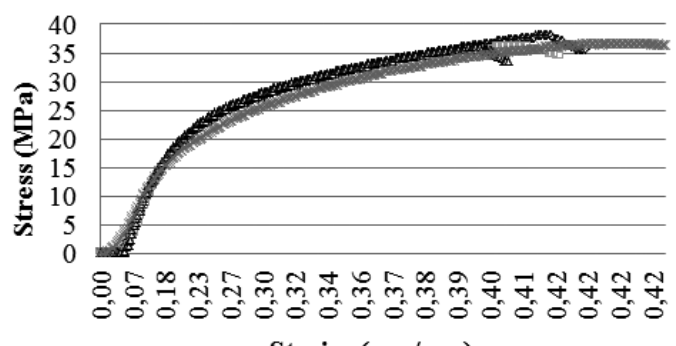

Strain $(\mathrm{mm} / \mathrm{mm})$ to fit the entire wall (see Figure 4). The tongue and groove joints bring an additional advantage of avoiding the use of cement mixtures to hold the bricks.

\subsection{Laboratory tests}

\section{Mechanical Properties Test}

Bricks and columns underwent tensile and compression testing. Such tests were performed under ASTM D638 and ASTM D695 respectively (American Society for Testing Materials, 2010). Figure 5 presents the stress-strain curves from the

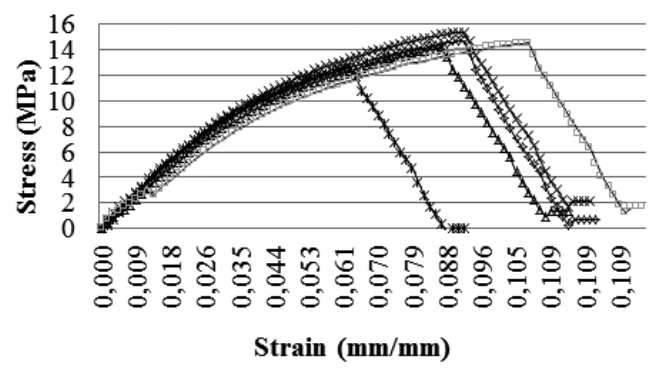

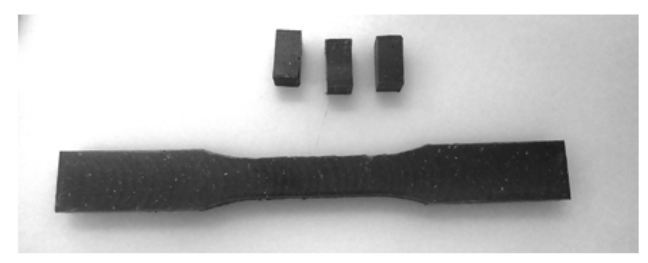

Figure 5. Compression Test (Left) y Tensile (right): plastic test specimen 1( $\downarrow)$, specimen

2(घ), specimen 3(山), specimen 4 (x). Plastic Test Specimens in compliance to ASTM. 
tensile and compression trials and the standardized plastic test specimens used. These curves reveal Ultimate Strength average values of $38 \mathrm{MPa}$ for the compression testing and 15,5 MPa for the tensile testing with a characteristic behavior of thermoplastic polymers (the graph only shows four specimens per test, however experiments were performed on 20 specimens and thus reducing uncertainty about the recorded values). Initially the graph shows a typical linear trend of an elastic deformation, corresponding to the stage where the initially amorphous polymer chains are undergoing a stretch to turn the material into a crystalline solid with polymer chains completely straight. This elastic deformation occurs because the weakest bonds also known as Van der Waals forces are the only bonds defeated by the effort. Once all chains are totally straight, the bonds to be broken are the strong covalent bonds between the molecules that make up the polymer chains and therefore a greater effort is required, when these covalent bonds are defeated, the material fails or fractures suddenly. The compression values in the specimens are higher than those of the traditional materials (i.e. the concrete has 32 MPa, (Natalini, 2002).

By testing the tensile, compressive and bending properties on another plastic test specimens made of different plastic mixtures, a certain divergence on the Ultimate Strengths was revealed, due to the presence of vacuums (internal bubbles) generated in the material extrusion and cooling. Figure 6 shows these interior vacuums. Material shrinkage due to post-extrusion cooling is done without adequate supervision to ensure homogenization throughout the solidified volume.

\section{Thermal Transmission Tests}

Given comfort is so relevant in housing design; one of the most important features to identify in these bricks is their thermal transmission properties. For this, a guardedhot-plate apparatus was constructed according to ASTMC177-10.(American Society for Testing Materials, 2010). Figure 7 shows the components of the device. The device is thermally insulated with a fiberglass cushion of $4 \mathrm{~cm}$ thick. Test seeks to determine the thermal transmission property of the material, based on the expression of heat transfer by conduction from Equation (1).

$$
Q_{\text {cond }}=\frac{K A}{L}\left(T_{\text {cal }}-T_{\text {fria }}\right)
$$

Where $K$ : heath conductivity factor of the material, A: Area of the section where the heat flows through, perpendicular to the direction of the heath flow $\left(\mathrm{m}^{2}\right), L$ : Thickness of the specimens $(\mathrm{m}), T_{\text {cal }}$ : Temperature of the heated surface between the electric heater resistance and the specimen $\left({ }^{\circ} \mathrm{C}\right), T_{\text {fria }}$ : Temperature of the cooled surface, between the water-cooling bloc and the specimen $\left({ }^{\circ} \mathrm{C}\right)$.
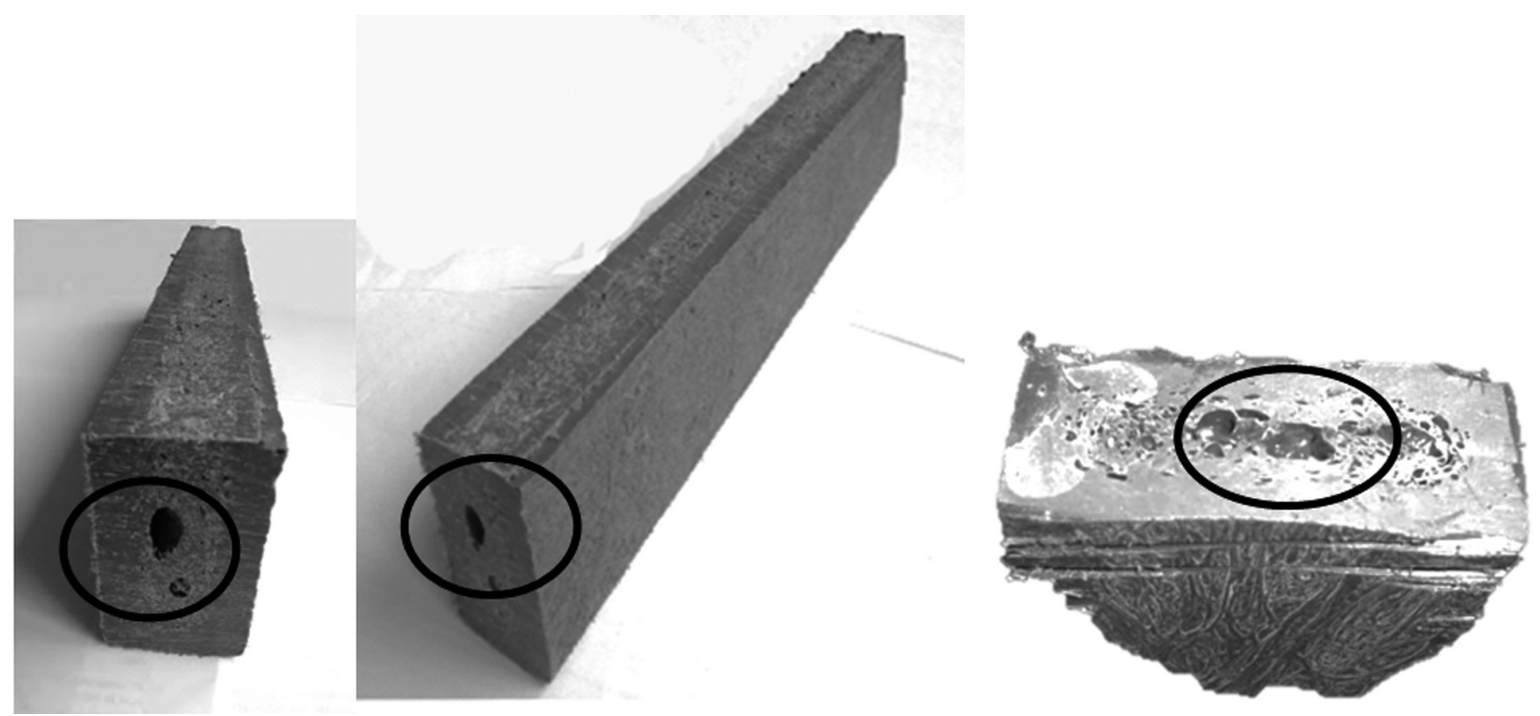

Figure 6. Sample of extruded plastic, vacuums and cracks presences. 


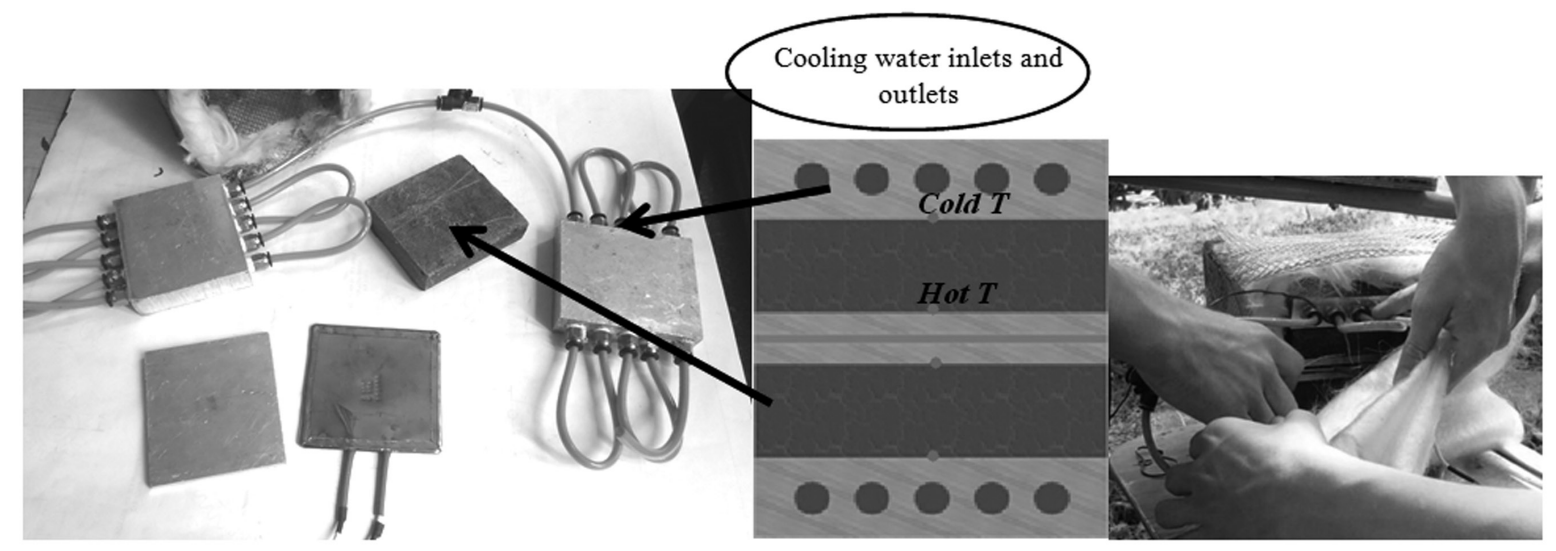

a)

b)

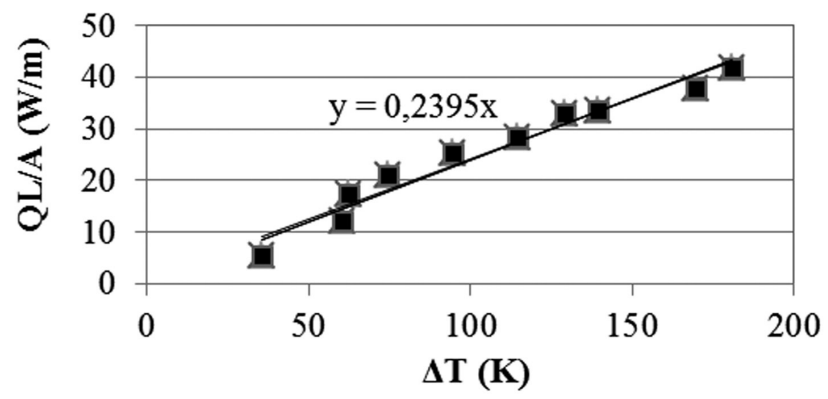

Figure 7. Guarded-hot-plate apparatus used in the Thermal Transmission Test according to ASTM C177, Upper and lower Water-cooling blocks, plastic test specimen and electric heater resistance, fiber glass cushion. a) Components of the device, b) Assembly scheme, c)Setup and Arrengement, d) Resulting Curve: $Q L / A=0,2395 \Delta T$.

Figure 7 shows the behaviour $Q_{\text {cond }} L / A$ vs $\Delta T$. The slope of this relationship determines a heath conductivity $K=0,24 \mathrm{~W} / \mathrm{mK}$, less than those of typical construction materials, some examples clay brick $(0,8 \mathrm{~W} / \mathrm{mK})$ harden cement $(1,07 \mathrm{~W} /$ $\mathrm{mK})$, concrete $(1,4 \mathrm{~W} / \mathrm{mK})$ and lime-and-sand masonry brick $(0,66 \mathrm{~W} / \mathrm{mK})$ (Milarium, 2010), this lower value guarantees acceptable thermal insulation conditions.

\section{Acoustic Insulation Tests}

Acoustic tests were conducted using a sound level meter located inside and outside the built module. For this test a sound source is located inside the module, at different frequencies and amplitudes, and inside and outside decibels were sensed and compared. From the test, an average decrease of $23,7 \%$ was detected. However, complete insulation is not accomplished due to clearances between walls and roof tiles. Some materials in the marketplace like GSI Sound-Stop Foam, has noise reduction levels around $21 \%$ and $30 \%$ for frequencies around 10 and $1000 \mathrm{~Hz}$ (González, 2002). This reveals another additional advantage of the plastic mixture used for the module. It may end up being a matter of study in other applications requiring noise insulation. It must be clear that in determining the levels of acoustic insulation, according to international standards (ASTM 423 90a), measurements should be taken under different frequencies in lab setting a wall between the sound source and receiver spaces perfectly isolated.

\section{Impermeability Tests}

This test is important because the structural and non-structural building bricks of any material are continuously exposed to the elements. Standard NTC 4017 (Colombian Technical Standard, 2005) rules the conditions for testing absorption of masonry bricks; it also suggests size and weight of specimens, temperature and drying time, and materials necessary to perform trials. For the test at hand, three plastic test specimens were made, by standard-compliance, their dimensions were $288 \mathrm{~mm}$ long, $183 \mathrm{~mm}$ high, $50 \mathrm{~mm}$ deep, and their weight was over $250 \mathrm{~g}$. The percentages of absorption from these tests average 3,8 \%. The 


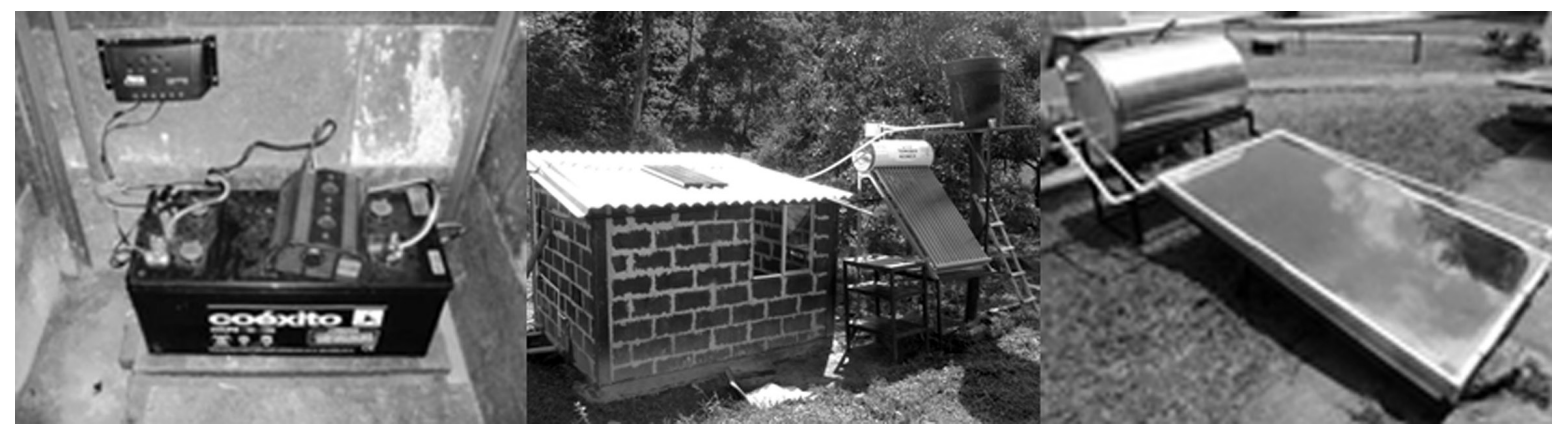

Figure 8. General and Final lay-out of the sustainable module housing: solar collector with vacuum tubes for $150 \mathrm{~L}$, Photovoltaic System for 600Wh/day (20 A charge controller, $400 \mathrm{~W}$ Power Inverter, 100 Ah battery) and flat plate solar collector

maximum percentage allowed by the standard NTC 4017 is $13 \%$, thus the bricks in the study feature a very low permeability, providing the module with good protection against weathering.

\subsection{Thermal and electric power systems}

For hot water at the disposal of children, elderly and sick people, a solar collector with vacuum tubes has installed that can raise the temperature up to $60^{\circ} \mathrm{C}$ and store up to 130 liters. The collector works by thermosyphon effect. Likewise, in case of greater thermal demands, a flat plate solar collector with heat exchanger was installed (Figure 8). To supply electricity the module was equipped with a stand-alone photovoltaic system to deliver 13,2
$\mathrm{kW}-\mathrm{h} /$ month, amount equivalent to the daily consumption of a pair of 20 watt light bulbs ( 6 hours), a 100 watt TV set (1 hour), a 10 watt (10 hours). The general setting of the housing module and the components of photovoltaic system can be seen in Figure 8. The project has involved the implementation of other systems such as small-scale wind turbine, a generator bicycle, as supplement to the available power supply for the module (Salazar, 2011).

\subsection{Cost}

The costs incurred in the housing module are recorded in Table 2. It can be seen that the construction costs amounted to COP 3.427 .000 (USD 1.713), excluding costs of renewable

Table 2. Incurred Costs in the Housing Module Building

\begin{tabular}{|c|c|c|c|c|}
\hline & Unit & Quantity & $\begin{array}{c}\text { Cost per } \\
\text { Unit (COP) }\end{array}$ & $\begin{array}{c}\text { Total } \\
\text { COP }\end{array}$ \\
\hline & whole & 143 & 9.000 & 1.287 .000 \\
\hline \multirow[t]{2}{*}{ Brick } & half & 70 & 4.000 & 280.000 \\
\hline & column & 5 & 100.000 & 500.000 \\
\hline Roof Tile & unit & 6 & 60.000 & 360.000 \\
\hline $\begin{array}{c}\text { Concrete } \\
\text { Base }\end{array}$ & unit & 1 & 500.000 & 500.000 \\
\hline $\begin{array}{l}\text { Bathroom } \\
\text { Combo and } \\
\text { drain pipes }\end{array}$ & unit & 1 & 300.000 & 300.000 \\
\hline $\begin{array}{c}\text { Electric } \\
\text { Wiring }\end{array}$ & & & 200.000 & 200.000 \\
\hline \multicolumn{4}{|c|}{ Total Cost of construction } & 3.427 .000 \\
\hline $\begin{array}{c}\text { Photovoltaic } \\
\text { System }\end{array}$ & unit & 1 & 2.500 .000 & 2.500 .000 \\
\hline \multirow[t]{3}{*}{$\begin{array}{c}\text { Solar } \\
\text { Collector }\end{array}$} & unit & 1 & 800.000 & 800.000 \\
\hline & & & Total COP & 6.727 .000 \\
\hline & & & Total USD & 3.363 \\
\hline
\end{tabular}


resources. The cost of the built square meter (COP 3.427.000/10,5 $\mathrm{m}^{2}=$ COP $326.380 / \mathrm{m}^{2}$ ) (USD 163) in this study is low in comparison to the costs of social welfare housing (COP $450.000 / \mathrm{m}^{2}$, USD 225 in Bogotá) reported in (Prieto, 2009), and keeping in mind that total construction area of the module is 10,5 $\mathrm{m}^{2}$. Nevertheless, the installation costs of the electrical and thermal systems that make the most of renewable sources are relatively high, but the long and mid turn energy savings (kWh) will make up for the high expenditures.

\section{Results and discussion}

As tangible and intangible results of this publication project basis, we can highlight: Building an environmentally sustainable housing module (with off-the-grid electricity and water supply with bricks of recycled plastic, use of solar energy as a renewable source for electricity generation (lighting and outlets) and thermal generation (heating water shower), rain water collector and septic tank for sewage treatment; fulfilling the need for housing of two elderly patients who needed to be isolated from the rest of the community, thermal comfort in warm and cold weather, due to the insulating property of the plastic; possibility of continuous hot water for sick children and adults of the community, active participation of the members of the community in the construction process of the module, contributing on their sense of belonging and self-esteem while accomplishing a common goal; from the environmental point of view, a fundamental contribution in promoting a culture of sustainability applied to house construction and efficient use of resources.

\section{Conclusions}

The use of reusable materials and renewable energy in operation resulted in savings on utilities bills and the investment return in a reasonable time compared to conventional construction. The type of construction ensures proper insulation for the thermal comfort the module requires. The module applies the use of renewable energy with solar energy, thermal potential for hot water, photovoltaic system for the electrical system. This project is a building model for the development of sustainable communities.

The developed work becomes an important reference for social and environmental nature projects that can be replicated at government level to build social housing, not only in the country but in Latin America.

The use of recycled plastic for housing construction becomes an important model for sustainable waste management. The progressive overpopulation and the consumer society, accompanied by a lack of sensitivity regarding the environment (mostly in Latin America) have led to an aggravated environmental crisis problems due to the excess of waste poured into natural sources without any control (rivers, forests, landfills, etc.). Taking into account large share percentage of plastic in the total waste, its reuse in social welfare projects becomes a significant contribution. Although the bricks in the project were made out of defective plastic discarded from industrial packaging (bags, PET bottles, etc.), it is feasible to exploit the future potential of plastic recycled from the waste as previously described.

Mechanical resistance, thermal, impermeability and sound tests have shown that these bricks outperformed other building materials in some important features (thermal and sound insulation and weather resistance, relative). However, some adjustments are needed in their production, like the control of mold cooling and better preparation of the raw material or mixture, to achieve better compacting process and homogenization of the bricks, and furthermore improve their properties.

One of the concerns about plastic material is the possibility of self-ignition, but empirical tests with plastic bricks in contact with fire showed that only some type of flame would last if the plastic were well saturated with liquid fuel. Any type of material has similar characteristics in these conditions, however, it is possible to improve this issue with plaster and fire resistant paint.

Additional energy transfer devices to be developed can provide significantly more energy 
available in a battery bank. However, it would be feasible for communities to install a microgrid connected to the main power system with direct energy inputs from the public utility.

The construction of social housing with plastic is completely feasible from the economic point of view. The cost of construction per square meter is competitive with current costs in the country, especially when there is evidence of an upward trend in the cost of housing by the government (Portafolio, 2012). But there are still another testings yet to perform like earthquake resistance and gas emissions, to assess the overall feasibility (technical, human, and economical) of this type of construction. A summary of the project in the social context has been published online (Canal Universitario Nacional Zoom 2011).

\section{References}

ASTM (American Society for Testing Materials). (2010). Standard Test Method for Compression Properties of Plastics. ASTM D695-10.

ASTM (American Society for Testing Materials). (2010). Test Method for Tensile Properties of Plastics. ASTM D638-10.

ASTM (American Society for Testing Materials). (2010). Standard Test Method for SteadyState Heat Flux Measurements and Thermal Transmission Properties by Means of the Guarded-Hot-Plate Apparatus, ASTM C177-10.

Bolaños, H2011, En Cali construyen primera casa con ladrillos de plástico reciclado, video online, Diciembre 8, visto 10 de julio de 2009, http:// www.youtube.com/watch? $\mathrm{v}=\mathrm{WZ} 3 \mathrm{HbmSR} 3 \mathrm{~T} 0$

Calcagno L. \& Ferrari, N. (2012). Planta para la fabricación de ladrillos ecológicos en base a plástico reciclado econstrucción S. A. IX Congreso Iberoamericano de Ingeniería de productos, Universidad de CAECE - Mar del Plata, Argentina.

Gaggino, Rosana. Ladrillos y placas prefabricadas con plásticos reciclados aptos para la autoconstrucción, revista INVI, Instituto de la Vivienda. Universidad de Chile, 23 (63), 137-163.
González,\& H.A. Orozco, C.A. (2002). Control de ruido: Marco Normativo y legal con aplicaciones en los sistemas de calefacción, ventilación, aire acondicionado y refrigeración $(\mathrm{CVAC} / \mathrm{R})$ de la UTP. Scientia et Technica 20 (3), 87-92.

Milarium, (2010). Propiedades térmicas de materiales, Ingeniería Civil y Medio ambiente. http://www.miliarium.com/Prontuario/Tablas/ Quimica/PropiedadesTermicas.asp

Ministerio de Ambiente, Vivienda y Desarrollo Territorial, República de Colombia. (2011). Calidad en la Vivienda de Interés Social. Documento preparado por el Ministerio del Ambiente de Colombia, Bogotá.

Natalini, Mario B. (2002). Estudio estadístico de Resistencia de materiales de construcción". Departamento de Estabilidad - Facultad de Ingeniería - UNNE. http://www.docstoc.com/ docs/3268681/Estudio-estad\%C3\%ADstico$\mathrm{de}-\mathrm{res}$ isten cia-de-materiales-deconstrucci\%C3\%B3n-Natalini-Mario.

NTC 4017, Norma Técnica Colombiana. (2005). Métodos para muestreo y ensayos de unidades de mampostería y otros productos de arcilla. http:// www.moore.com.co/icontec/4205.htm

Pineda, A. (2012). Desarrollo del arquetipo del bio ladrillo bioblock a partir de cáscara de arroz mezclado con plástico y una mezcla aglutinante. Tesis de posgrado, Universidad Libre, Colombia.

Portafolio, dic 11 de 2012. Nota: Precio de vivienda prioritaria sube en 7 departamentos. http://www.portafolio.co/economia/preciovivienda-prioritaria-colombia

Presidencia de la República. (1991). Constitución Política de Colombia. Documento elaborado por la presidencia de la república de Colombia, Bogotá.

Prieto, J.,\& Flórez, M. (2009). Estudio económico de sistemas estructurales prefabricados para vivienda de interés social. Universidad de Los Andes. http://micigc.uniandes.edu. co/Investigaciones $\% 20 y \% 20$ Desarrollo/ estudioeconomico.pdf 
Salazar, E., Arroyave, J.F.,\& Castro, W. (2011). Energías Alternativas, experiencias desde el semillero de investigación en Tecnología Mecánica", Scientia et Technica 3 (49). 260-265.

Secretaría de Planeación, alcaldía de Pereira. (2008). Caracterización de residuos sólidos urbanos en el municipio de Pereira. Documento preparado por la Universidad Tecnológica de Pereira.
Sun Chi,\& Ann Tin Wan. (2004). Management of construction waste in public housing projects in Hong Kong. Construction Managnment Economics 22 (7), 675-689.

Zoom Canal Universitario Nacional 2011, Viviendas Ecosostenibles H264, video online, Julio 6, visto 6 de agosto de 2013, http://www. youtube.com/watch?v=AAWAAV_5F3g 